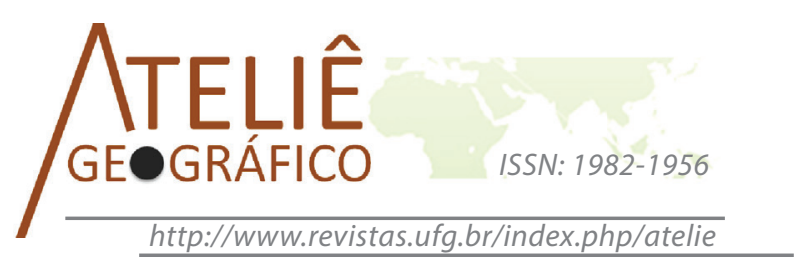

\title{
Territorialização do capital e resistência camponesa em Dracena - SP
}

\author{
Territorialization of capital and peasant resistance \\ in Dracena - SP
}

\section{Territorialización del capital y la resistencia campesina en Dracena - SP}

\author{
Leandro Reginaldo Maximino Lelis \\ Universidade Federal do Rio Grande do Norte \\ sukko51@hotmail.com \\ Francisco José Avelino Júnior \\ Universidade Federal de Mato Grosso do Sul \\ china.ufms@hotmail.com
}

\begin{abstract}
Resumo
A territorialização do capital no campo, em Dracena, ocorreu por meio da monocultura canavieira, que se expandiu neste município no início da década de 2000. No município de Dracena, a territorialização da cana-de-açúcar tem se configurado como obstáculo para o desenvolvimento do campesinato. Neste contexto, este trabalho tem como objetivo analisar a resistência camponesa frente à territorialização do capital, representado, em Dracena, pela monocultura canavieira. A partir da leitura do material bibliográfico selecionado e da análise dos dados de fontes secundárias e dos questionários aplicados junto aos camponeses de Dracena, constatou-se que a territorialização da monocultura canavieira tem provocado diversos impactos socioambientais. Entretanto, apesar do contexto desfavorável, a maior parte dos camponeses pesquisados informou que pretende permanecer no campo, evidenciando a resistência camponesa perante as adversidades impostas pela territorialização do capital.
\end{abstract}

Palavras-chave: territorialização do capital; cana-de-açúcar; resistência camponesa; Dracena.

\footnotetext{
Abstract

The territorialization of capital over the field in Dracena has occurred through sugarcane monoculture and its expansion since the 2000s, a process that creates obstacles to the development of peasantry. This paper examines the peasant
} 
resistance against the territorialization of capital in Dracena, represented by sugarcane monoculture. Based on theoretical frameworks, analysis of data from secondary sources and questionnaires, we found that the territorialization of sugarcane monoculture has led to several social and environmental impacts. Despite this unfavorable context, most peasants reported that plan to stay in the field, showing their resistance to adversities imposed by the territorialization of capital.

Keywords: territorialization of capital; sugarcane; peasant resistance; Dracena.

\section{Resumen}

La territorialización del capital en el campo, en Dracena, ocurrió a través del monocultivo de caña de azúcar que se ha expandido en este municipio en la década de 2000. En Dracena, la territorialización de la caña de azúcar se ha configurado como un obstáculo para el desarrollo del campesinado. En este contexto, este trabajo tiene como objetivo analizar la resistencia campesina delante de la territorialización del capital, representado, en Dracena, por el monocultivo de caña de azúcar. A partir de la lectura de la bibliografía seleccionada y el análisis de datos de fuentes secundarias y de los cuestionarios aplicados junto a los campesinos de Dracena, ha verificado qué la territorialización del monocultivo de caña de azúcar causó varios impactos sociales y ambientales. Sin embargo, aunque del contexto desfavorable, la mayor parte de los campesinos investigados informó que tiene la intención de permanecer en el campo, lo que evidencia la resistencia campesina ante las adversidades impuestas por la territorialización del capital.
\end{abstract}

Palabras clave: territorialización del capital; caña de azúcar; resistencia campesina; Dracena.

\title{
Introdução
}

O processo de territorialização do capital no campo e a consequente modernização da agricultura foram fundamentais para viabilizar a expansão das monoculturas no Brasil, como é o caso da cana-de-açúcar. A territorialização da monocultura canavieira, em Dracena, ocorreu no início da década de 2000 em virtude, principalmente, da tendência mundial para a utilização de combustíveis menos poluentes e originados a partir de fontes renováveis de energia (GIL, 2007; JOVIANO, 2009).

No município de Dracena, a territorialização da cana-de-açúcar tem provocado inúmeros impactos socioambientais. Entre estes impactos está a dificuldade para o desenvolvimento do campesinato. Neste contexto, este trabalho tem como objetivo analisar a resistência camponesa frente à territorialização do capital, representado, em Dracena, pela monocultura canavieira.

Para alcançar o objetivo proposto, delineamos os seguintes procedimentos metodológicos: pesquisa bibliográfica e leitura do material selecionado; coleta de dados de fontes secundárias; e, trabalho de campo para aplicação de questionários semiabertos junto aos camponeses. A pesquisa bibliográfica foi realizada acerca dos seguintes temas: territorialização do capital no campo; modernização da agricultura; resistência camponesa; e, expansão da cana-de-açúcar no Oeste do Estado de São Paulo. Os dados de fontes secundárias foram obtidos junto à Comissão Pastoral da Terra (CPT) e ao Instituto 
Brasileiro de Geografia e Estatística (IBGE). O recorte temporal delineado para obtenção dos dados de fontes secundárias compreendeu o período entre os anos de 2000 e 2013 . O questionário foi aplicado junto a 25 camponeses de Dracena. Acreditamos que a escolha de 25 camponeses de diferentes locais ${ }^{1}$ do município possibilitou amostra significativa no que diz respeito à realidade dos camponeses da localidade pesquisada. Procuramos diversificar os locais de aplicação de questionário com intuito de conhecer amplamente a realidade dos camponeses dracenenses. Além dos questionários semiabertos, utilizamos gravador de voz para capturar depoimentos dos camponeses pesquisados. O trabalho de campo foi realizado nos dias 13, 19 e 26/03/2015 e no dia 02/04/2015.

\section{A territorialização do capital e a modernização da agricultura brasileira}

Para Oliveira (1996b), o processo de desenvolvimento do capitalismo no campo é marcado pela industrialização da agricultura. Além disso, ao tornar possível a apropriação da renda da terra pelos proprietários de terras e pelos capitalistas/proprietários de terras, o desenvolvimento da agricultura capitalista viabilizou a ampliação da concentração fundiária no Brasil. Ainda segundo o autor, a territorialização do capital é a principal marca desse processo.

Segundo Oliveira (1996b), quando o capital se territorializa, não é necessário que os trabalhadores permaneçam no campo. Por isso eles vão para as cidades e concentram-se, principalmente, nas periferias. Na cidade esses trabalhadores vão para o setor industrial, comercial ou de serviços. Esses trabalhadores também podem ser utilizados como trabalhadores assalariados no campo, mais conhecidos como "bóiasfrias" (OLIVEIRA, 1996b). No caso da territorialização do capital:

[...] o processo especificamente capitalista se instala e a reprodução ampliada do capital desenvolve-se em sua plenitude. O capitalista/proprietário da terra acumula simultaneamente o lucro da atividade industrial e agrícola (da cultura da cana, por exemplo) e a renda da terra gerada por essa atividade. A monocultura se implanta e define e caracteriza o campo, transformando a terra num "mar" de cana, de soja, de laranja, de pastagem etc (OLIVEIRA, 1996b, p. 478).

Oliveira (1996b) cita as usinas e destilarias de açúcar e álcool como exemplo do processo de territorialização do capital, pois conforme o autor:

[...] indústria e agricultura são partes ou etapas de um mesmo processo. Capitalista da indústria, proprietários de terra e capitalista da agricultura têm um só nome, são uma só pessoa ou uma só empresa. Para produzir, utilizam o trabalho assalariado dos "bóias-frias" que moram e vivem nas cidades (OLIVEIRA, 1996b, p. 478).

1. Selecionamos cinco locais em que a presença do campesinato é predominante. Em cada um dos cinco locais foram aplicados cinco questionários, totalizando 25 questionários. Os locais selecionados foram os bairros rurais Marrequinha, Palmeiras, Palmeirinha, o Distrito de Jamaica e o Assentamento Nova Canaã. 
A territorialização do capital no campo foi fundamental para viabilizar a modernização da agricultura no Brasil. Até a década de 1950, a agricultura era considerada como o setor tradicional da economia que prejudicava o desenvolvimento industrial no Brasil. Isso ocorria em função de sua incapacidade de fornecer a quantidade necessária de matéria-prima para as fábricas, bem como pelo pequeno poder de compra dos trabalhadores agrícolas, impossibilitando o consumo de produtos industrializados (ANDRANDE, 1979).

A partir da década de 1950, esse pensamento foi alterado e a agricultura passou a ser vista como uma forma de inserção do Brasil na economia internacional. Entretanto, para que isso ocorresse, seria necessário aumentar a produção e a produtividade agrícola (ANDRADE, 1979). Assim, para o Estado brasileiro, essa situação poderia ser superada pela “[...] introdução de métodos mais modernos nas relações de produção que promoveriam o aumento da produtividade da terra e do trabalho e, consequentemente, $\mathrm{o}$ desenvolvimento" (MATOS; PESSÔA, 2011, p. 294).

Desse modo, a partir década de 1950, o Estado propagou a ideia de que a modernização da agricultura seria necessária para o desenvolvimento econômico do país. No entanto, somente a partir da década de 1960, a modernização da agricultura consolidou-se no campo brasileiro. A partir daquela década, o Brasil reestruturou sua base produtiva em decorrência da modernização agrícola (ANDRADE, 1979; MATOS; PESSÔA, 2011).

A modernização do campo brasileiro transformou a agricultura em uma atividade pautada no lucro e regulada pelo mercado internacional (OLIVEIRA, 2003). Desse modo, Oliveira (2003) aponta que o campo brasileiro está cada vez mais submetido ao mercado internacional e à lógica contraditória da mundialização do capital.

O Governo Federal teve papel fundamental para a consolidação da modernização da agricultura no Brasil. Por meio dos órgãos governamentais realizaram-se uma série de investimentos. Além disso, o Estado mobilizou-se para implantar a infraestrutura necessária para a consolidação da modernização agrícola (MATOS; PESSÔA, 2011).

A desigualdade foi a marca na destinação desses investimentos. Enquanto os grandes proprietários capitalistas usufruíram de vantagens e facilidades, os camponeses sofreram com a falta de apoio e incentivo governamental, ficando, dessa forma, marginalizados perante os investimentos estatais no espaço rural brasileiro (ANDRADE, 1979). A respeito dos benefícios concedidos à agricultura praticada em grande escala, Andrade (1979) escreve:

Procura-se montar todo um sistema que visa proteger e subvencionar a grande agricultura, estimulando-se o processo de mecanização agrícola, facilitando-se o crédito para formação de plantios e para a implantação e modernização de instalações, a assistência agronômica etc. em favor da agricultura de exportação (ANDRADE, 1979, p. 62).

Ressaltando o papel do Estado no setor agrícola, para Martins (1975) a política econômica estatal regula o setor externo e o setor interno. Desse modo, os produtos 
agrícolas destinados ao mercado externo e interno são regulados pelo Estado, “[...] seja porque deles depende substancialmente a receita cambial do país, empregada na industrialização, seja porque passaram a ter consumo expressivo ou preponderante no mercado interno" (MARTINS, 1975, p. 59).

Segundo Matos e Pessoa (2011), a criação de instituições de pesquisa foi fundamental para viabilizar a expansão da agricultura moderna. Nesse caso se enquadra a Empresa Brasileira de Pesquisa Agropecuária (EMBRAPA), criada em 1971. As pesquisas científicas desenvolvidas pela EMBRAPA passaram a ser realizadas “[...] para o melhoramento da produção, na tentativa de corrigir as deficiências dos solos, prevenir doenças, aumentar o rendimento por hectares, atender as exigências do mercado quanto a variedade produzida, tamanho, sabor etc [...]" (MATOS; PESSÔA, 2011, p. 303). Dessa forma, a partir de sua criação, a EMBRAPA passou a coordenar e executar pesquisas científicas visando desenvolver as atividades agropecuárias praticadas no Brasil.

Os meios de comunicação foram importantes para a consolidação do processo de modernização da agricultura, pois disseminaram a ideia de que a modernização agrícola e o consequente aumento da produção e da produtividade beneficiariam a população. Assim, os meios de comunicação difundiram os danos sociais e ambientais como prejuízos necessários para o desenvolvimento e progresso do Brasil (ANDRADE, 1979). Neste sentido, Almeida (2012) corrobora:

[...] o desenvolvimento econômico é um mito cuja funcionalidade é criar um imaginário coletivo centrado na ideia de que todos serão beneficiados pelo desenvolvimento do capital, situação que leva os povos a aceitar sacrifícios que incluem formas de dependência e de destruição do meio físico (ALMEIDA, 2012, p. 12).

Para Martins (1975), existe valorização do "moderno" contra o "tradicional" em diversos âmbitos da sociedade. Segundo o autor, enquanto o "moderno" está ligado ao urbano, o "tradicional" está ligado ao rural. Essa valorização faz parte da ideologia da urbanização e contribuiu para propagar os benefícios da modernização das atividades agrícolas.

De acordo com Matos e Pessôa (2009), a modernização da agricultura proporcionou muito mais desvantagens do que vantagens. Como vantagens, as autoras citam o aumento da produção e da produtividade agropecuária em função das inovações tecnológicas. Como desvantagens, apontam que esse processo contribuiu para ampliar a concentração fundiária e de renda, a precarização do trabalho, além de aumentar as desigualdades regionais, expulsar milhares de famílias do campo, proporcionar a destruição e poluição do meio ambiente, entre outros. Nesse sentido, as autoras pontuam que a modernização "[...] foi uma falsa imagem de progresso, um mito, produto do discurso de desenvolvimento rural” (MATOS; PESSÔA, 2011, p. 301).

Neste contexto, segundo Graziano da Silva (1982), o que se vê no campo brasileiro é uma modernização conservadora e dolorosa. Conservadora porque privilegia somente algumas culturas (principalmente as destinadas ao mercado externo) e regiões, 
bem como, somente alguns tipos de unidades produtivas (médias e grandes propriedades rurais). Dolorosa porque gerou graves contradições sociais em decorrência da expansão da lógica capitalista. Assim, o processo de modernização do campo brasileiro nunca possuiu caráter dinâmico e homogêneo, pelo contrário, implicou em "[...] pesados custos sociais e que só vinga pelo amparo do Estado" (GRAZIANO DA SILVA, 1982, p. 40).

A territorialização do capital no campo e a consequente modernização da agricultura foram responsáveis por provocar alterações significativas na dinâmica social, econômica e ambiental do campo brasileiro, proporcionando diversos impactos socioambientais.

\section{Resistência camponesa e os conflitos no campo}

De acordo com Oliveira (1996b), o campo brasileiro está marcado por seu caráter contraditório, pois ao mesmo tempo em que ocorre a expansão do trabalho assalariado e do trabalho familiar no campo, também ocorre a ampliação da concentração fundiária “[...] e da luta pela 'abertura' da terra pelos camponeses, quer pela ampliação das áreas de posse, quer pela conquista das terras que a luta pela reforma agrária tem conseguido transformar em terra camponesa" (OLIVEIRA, 1996b, p. 481).

Segundo Oliveira (1996a), as transformações estruturais do campo brasileiro desencadearam as lutas pela terra no campo pela reforma agrária. Em relação à reforma agrária, Oliveira (1996b) assinala:

[...] além de resolver a maior parte dos problemas estruturais que existem no campo brasileiro, permitirá ampliar a oferta de alimentos e resolver o problema crônico da fome e do desemprego - enfim, da miséria que envolve milhões de brasileiros (OLIVEIRA, 1996b, p. 534).

A luta dos trabalhadores rurais brasileiros pela reforma agrária, por meio de estratégias, como manifestações, ocupações, acampamentos e assentamentos, se configura "[...] como processo de territorialização da luta e resistência camponesa diante a monopolização do território pelo capital” (BEDUN, 2012, p. 43). Deste modo, por meio dos movimentos sociais, os trabalhadores rurais confrontam a lógica estabelecida pelo capital.

De acordo com Fabrini (2010), por meio das lutas realizadas pelos movimentos sociais rurais, com destaque para as ocupações de terra e acampamentos, os camponeses resistem ao projeto de "desenvolvimento" para o campo brasileiro viabilizado pelo capital.

Fabrini (2011) aponta que ao participarem dos movimentos sociais os camponeses resistem às perversidades impostas pelo capitalismo.

Diante desse contexto, os camponeses organizados nos movimentos sociais [...] resistem bravamente ao projeto de desenvolvimento das oligarquias e empresários rurais, indicando que os conflitos sociais são também conflitos territoriais: o território do agronegócio e latifúndio em contraposição ao 
território camponês. Acrescenta-se que o território camponês é portador de um conjunto de práticas não-capitalistas, como produção de autoconsumo e resistência, controle relativo do processo produtivo, autonomia, relações comunitárias e solidárias, dentre outras (FABRINI, 2011, p.110).

Para Almeida (2006), a luta dos movimentos sociais rurais pela terra representa a ruptura na territorialização e monopolização do território pelo capital.

O acampamento e o assentamento são transformações que o território contém, o que ocorre por meio da territorialização da luta pela terra, e que, portanto, representam uma ruptura no processo de territorialização e monopolização do território pelo capital. Assim, quando falamos em territorialização da luta pela terra, estamos, pois, referindo-nos às frações do território conquistadas pelos camponeses, em oposição à lógica de territorialização do capital monopolista, bem como à de monopolização do território pelo capital monopolista. Essa ruptura produz imagens territoriais que, se, por um lado, geram distinção em relação à apropriação capitalista, por outro, expressam identidade camponesa (ALMEIDA, 2006, p. 342).

De acordo com Bedun (2012), a luta dos movimentos sociais pela terra e contra o "[...] capital fortalece a classe camponesa por meio de sua resistência e (re) criação" (BEDUN, 2012, p. 48). Além disso, essa luta evidencia a resistência camponesa à expropriação, violência, exploração e sujeição provocadas pelo desenvolvimento do capitalismo no campo. Ainda para a autora: "as diversas manifestações e lutas desenvolvidas no campo pelos camponeses apontam para uma idéia de resistência e (re) criação contra a expropriação regida pela lógica capitalista” (BEDUN, 2012, p. 40).

Fabrini (2010) afirma que os assentamentos de reforma agrária são resultados importantes das lutas camponesas. Para o autor supracitado, os assentamentos de reforma agrária constituem-se como importantes frações do território camponês. Ainda segundo o autor, nesses territórios camponeses, antigas e novas sociabilidades são reavivadas e recriadas a partir da conquista da terra.

De acordo com Almeida (2006), a luta pela terra deve ser entendida como uma luta contra o capital, tendo em vista que uma reforma agrária de caráter apenas distributivo mantém a renda subjugada ao capitalista, mantendo a sujeição do trabalhador camponês perante o capital. Para Oliveira (1995, p. 81): “[...] a luta pela terra não pode-se restringir apenas e especificamente, à luta pelo direito do acesso à terra; deve, isto sim, ser a luta contra quem está por trás da propriedade capitalista da terra, ou seja, o capital”.

Ao lutarem pela terra e pela reforma agrária, os movimentos sociais rurais “[...] têm se desenvolvido na contramão do discurso desenvolvimentista respaldado pelo agronegócio e apregoado pelo capital” (BEDUN, 2012, p. 59). Tal situação faz com que:

As elites concentradoras de terra respondem com a barbárie. Assim, o país vai prosseguindo no registro das estatísticas crescente sobre os conflitos e a violência no campo. A luta sem trégua e sem fronteiras que travam os camponeses e trabalhadores do campo por um pedaço de chão e contra as múltiplas formas 
de exploração de seu trabalho amplia-se por todo canto e lugar, multiplica-se como uma guerrilha civil sem reconhecimento. Essa realidade cruel é a face da barbárie que a modernidade gera no Brasil (OLIVEIRA, 2007, p. 151-152).

Os conflitos existentes no campo, sobretudo os oriundos das disputas territoriais entre os camponeses e o capital, evidenciam a luta dos movimentos sociais pela terra e "[...] o enfrentamento do camponês a uma estrutura agrária calcada na concentração fundiária e monopolizada pelo capital” (BEDUN, 2012, p. 49-50).

No que se refere à disputa territorial entre o capital e o campesinato, Paulino e Almeida (2010, p. 58) constatam: "de um lado, a classe daqueles que usam a terra para extrair renda e lucro e produzir dominação política; do outro, a classe dos camponeses que da terra precisam para viver. O resultado tem sido um território em disputa!".

As disputas territoriais entre o campesinato e o capital indicam lógicas divergentes de organização e produção no campo. Enquanto o camponês desenvolve suas atividades na propriedade familiar e produz de maneira diversificada para satisfazer suas necessidades básicas, o capitalista “[...] organizado na grande propriedade fundiária, baseada na monocultura exportadora, vive do lucro, fruto da exploração da força de trabalho" (BEDUN, 2012, p. 90-91).

Para Girardi e Fernandes (2009, p. 363): “[...] a violência tem sido utilizada pelo latifúndio e pelo agronegócio para expropriar e impedir a territorialização e a reterritorialização do campesinato". Destarte, a violência é utilizada pelos capitalistas para reprimir a luta camponesa pela terra. Nesse sentido, segundo Oliveira (2007, p.135) a "[...] violência tem sido a principal característica da luta pela terra no Brasil".

No Brasil das últimas décadas, um grande número de conflitos, em geral sangrentos, tem acontecido no campo. Lideranças sindicais de trabalhadores, religiosos, advogados entre outros, têm sido cruelmente assassinados ao arrepio da lei. A justiça continua ser a única ausente do campo nos dias de hoje (OLIVEIRA, 1996, p. 7).

A Figura 1 apresenta os dados dos conflitos no Brasil entre os anos de 2000 e 2013. Entre os tipos de conflitos estão: conflitos por terra, conflitos por água, conflitos trabalhistas, entre outros. Entre os anos de 2000 e 2013, o número de conflitos de terras passou por oscilações. No entanto, a partir de 2003, todos os anos registraram mais de 1.000 conflitos. Isso não quer dizer que antes de 2003 existiam menos conflitos no campo, mas sim, que eram menos divulgados. De acordo com Bedun (2012), os conflitos existentes no campo brasileiro não são amplamente divulgados, “[...] uma vez que a história do Brasil sempre esteve voltada para a classe dominante, controlada por latifundiários e capitalistas, e não em torno da luta e mobilização da classe de trabalhadores" (BEDUN, 2012, p. 60). 


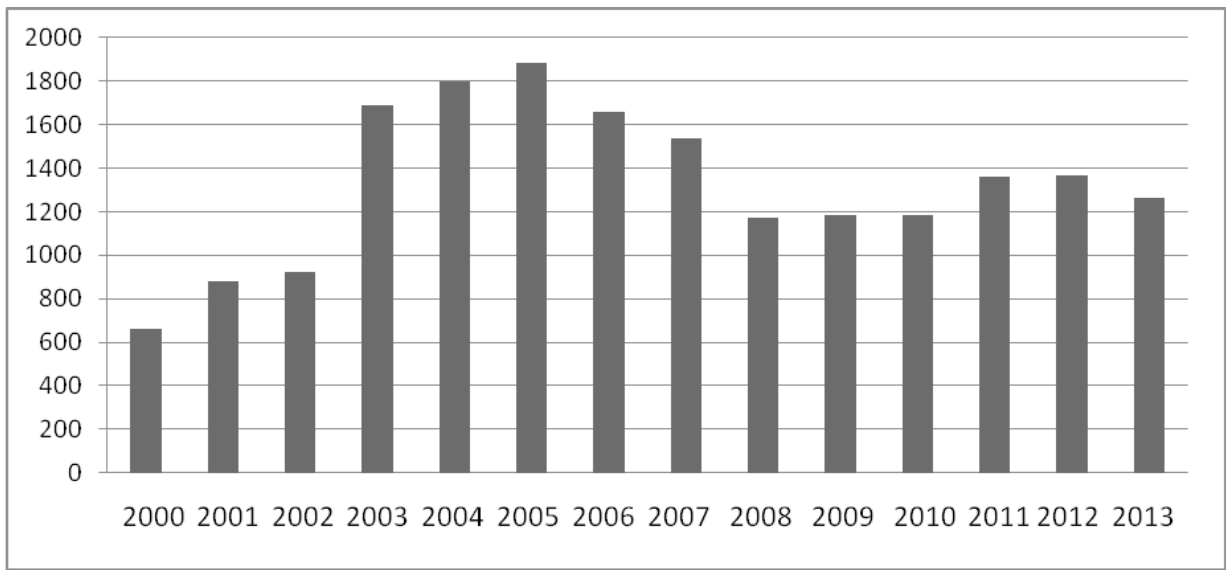

Figura 1. Brasil: conflitos no campo (2000 - 2013) Fonte: Comissão Pastoral da Terra, 2015.

Os conflitos entre o capital e o campesinato, no geral, tem se caracterizado pela barbárie e violência. Assim, esses conflitos têm custado vidas. A Figura 2 apresenta os dados referentes ao número de assassinatos ocorridos durante os conflitos no Brasil entre os anos de 2000 e 2013. Em 14 anos de conflitos foram registrados 497 assassinatos.

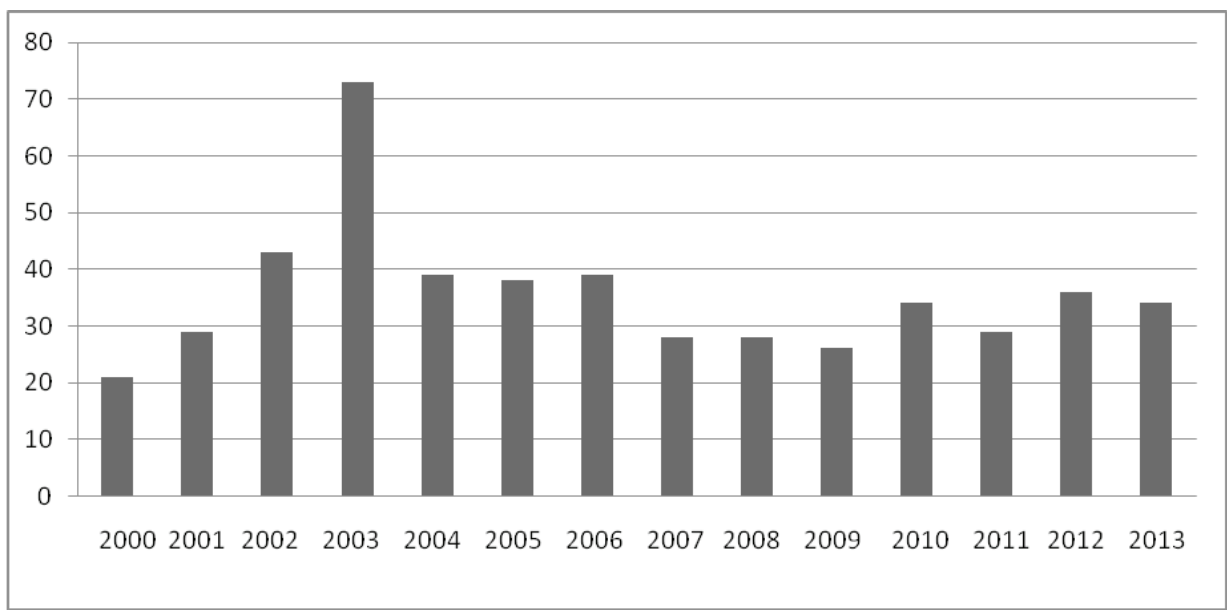

Figura 2. Brasil: assassinatos em conflitos no campo (2000 - 2013)

Fonte: Comissão Pastoral da Terra, 2015.

Para Bedun (2012), as tensões e a violência presentes nos conflitos agrários são evidencias das contradições existentes no desenvolvimento do capitalismo no campo. Conforme a autora, as contradições do capitalismo refletem "[...] o processo de 
uso e exploração do território. Neste contexto, o camponês é atingido pela violência da subordinação, exploração e expropriação, a partir da lógica desigual e contraditória do capital" (BEDUN, 2012, p. 61).

Thomaz Júnior (2009) afirma que a violência utilizada pelos capitalistas e pelo Estado contra trabalhadores rurais, dirigentes sindicais e militantes dos movimentos sociais é uma marca dos conflitos agrários brasileiros.

O expediente da violência e da truculência adotados pelas classes dominantes e pelo próprio Estado sustenta marcas indeléveis, tanto no que se refere aos assassinatos, quanto às perseguições e desaparecimentos de trabalhadores (posseiros, assalariados, pequenos produtores, etc), dirigentes sindicais e militantes dos diversos movimentos sociais envolvidos na luta pelo acesso à terra e resistência nela (THOMAZ JÚNIOR, 2009, p. 85).

Apesar da constante repressão e violência, Thomaz Júnior (2009) aponta que essas barbáries não exterminaram o envolvimento e a luta dos trabalhadores pelo acesso a terra, por melhores condições no campo, dentre outros objetivos.

Nesse sentido, a repressão e a violência que engordam as fatídicas estatísticas das torturas, dos assassinatos, dos desaparecimentos de camponeses, lideranças sindicais e trabalhadores rurais, bem como o comprometimento da maioria do Poder Judiciário com os imperativos do capital e do latifúndio, não fizeram desaparecer o envolvimento e a luta dos trabalhadores, sintonizados com o desejo do acesso a terra, à Reforma Agrária, às melhores condições de trabalho, ao cumprimento dos direitos trabalhistas, às denúncias de trabalho escravo etc. (THOMAZ JÚNIOR, 2009, p. 367).

Assim, mesmo com a violência utilizada pelos capitalistas, o campesinato segue sua trajetória de luta para entrar e permanecer na terra, resistindo às perversidades impostas pelo desenvolvimento do capitalismo no campo.

\section{A territorialização da cana-de-açúcar no município de Dracena}

No município de Dracena, a territorialização da monocultura canavieira ocorreu a partir do início da década de 2000. Diversos fatores contribuíram para a referida territorialização, porém o mais significativo foi o aumento do consumo dos biocombustíveis em decorrência da tendência mundial para utilização de combustíveis menos poluentes e provenientes de fontes renováveis de energia (GIL, 2007; JOVIANO, 2009).

A partir do ano de 2001, cinco agroindústrias sucroalcooleiras foram instaladas na Microrregião Geográfica² ${ }^{2}$ e Dracena. Em 2001, no município vizinho de Junqueirópolis, foi instalada a Usina Alta Paulista. No ano de 2006, três usinas sucroalcooleiras foram inauguradas, sendo uma em Dracena e duas em municípios próximos: Usina Dracena

2. Municípios que integram a Microrregião Geográfica de Dracena: Dracena, Irapuru, Junqueirópolis, Monte Castelo, Nova Guataporanga, Ouro Verde, Panorama, Paulicéia, Santa Mercedes, São João do Pau D’Alho e Tupi Paulista. 
Álcool e Açúcar Ltda, em Dracena; Usina Rio Vermelho Álcool e Açúcar Ltda, em Junqueirópolis; e, Destilaria Caiuá S/A, em Santa Mercedes. Em 2009, inaugurou-se a Usina Caeté S/A, no município de Paulicéia (GIL, 2007; JOVIANO, 2009).

A partir desse período, Dracena consolidou-se como centro regional do setor sucroalcooleiro, pois as agroindústrias sucroalcooleiras localizadas em municípios próximos instalaram escritórios em Dracena, em função da amplitude do setor de serviços dessa cidade, com destaque para o setor bancário, que oferece quantidade maior de agências.

A instalação das usinas sucroalcooleiras proporcionou a territorialização do monocultivo de cana-de-açúcar em todos os municípios da Microrregião Geográfica de Dracena. Entre os anos de 2000 e 2013, por exemplo, a área ocupada pela cana-de-açúcar na microrregião em questão foi ampliada em $35.577,9 \%$ (Tabela 1).

Tabela 1. Microrregião de Dracena - SP: área plantada de cana-de-açúcar (2000 - 2013)

\begin{tabular}{|l|c|c|c|c|}
\hline \multirow{2}{*}{ Tipo de lavoura } & $\mathbf{2 0 0 0}$ & $\mathbf{2 0 0 5}$ & $\mathbf{2 0 1 0}$ & $\mathbf{2 0 1 3}$ \\
\cline { 2 - 5 } & Área (hectares) & Área (hectares) & Área (hectares) & Área (hectares) \\
\hline Cana-de-açúcar & 280 & 11.496 & 82.802 & 99.898 \\
\hline
\end{tabular}

Fonte: Produção Agrícola Municipal - IBGE, 2015.

Neste mesmo período, a quantidade produzida de cana-de-açúcar apresentou crescimento de $55.527,8 \%$, passando de 14.000 toneladas, em 2000, para 7.787 .885 toneladas, em 2013 (Tabela 2).

Tabela 2. Microrregião de Dracena - SP: quantidade produzida de cana-de-açúcar (2000 - 2013)

\begin{tabular}{|l|c|c|c|c|}
\hline \multirow{2}{*}{ Tipo de lavoura } & $\mathbf{2 0 0 0}$ & $\mathbf{2 0 0 5}$ & $\mathbf{2 0 1 0}$ & $\mathbf{2 0 1 3}$ \\
\cline { 2 - 5 } & $\begin{array}{c}\text { Quantidade } \\
\text { (toneladas) }\end{array}$ & $\begin{array}{c}\text { Quantidade } \\
\text { (toneladas) }\end{array}$ & $\begin{array}{c}\text { Quantidade } \\
\text { (toneladas) }\end{array}$ & $\begin{array}{c}\text { Quantidade } \\
\text { (toneladas) }\end{array}$ \\
\hline Cana-de-açúcar & 14.000 & 883.387 & 7.305 .791 & 7.787 .885 \\
\hline
\end{tabular}

Fonte: Produção Agrícola Municipal - IBGE, 2015.

O valor gerado pela produção de cana-de-açúcaré outro indício da territorialização da monocultura canavieira na Microrregião de Dracena, tendo em vista que entre 2000 e 2013, houve expressivo aumento de $173.431,2 \%$ (Tabela 3 ).

Tabela 3. Microrregião de Dracena - SP: valor da produção da cana-de-açúcar (2000 - 2013)

\begin{tabular}{|l|c|c|c|c|}
\hline \multirow{2}{*}{ Tipo de lavoura } & $\mathbf{2 0 0 0}$ & $\mathbf{2 0 0 5}$ & $\mathbf{2 0 1 0}$ & $\mathbf{2 0 1 3}$ \\
\cline { 2 - 5 } & $\begin{array}{c}\text { Valor } \\
\text { (mil reais) }\end{array}$ & $\begin{array}{c}\text { Valor } \\
\text { (mil reais) }\end{array}$ & $\begin{array}{c}\text { Valor } \\
\text { (mil reais) }\end{array}$ & $\begin{array}{c}\text { Valor } \\
\text { (mil reais) }\end{array}$ \\
\hline Cana-de-açúcar & 250 & 24.735 & 298.287 & 433.828 \\
\hline
\end{tabular}

Fonte: Produção Agrícola Municipal - IBGE, 2015. 
A territorialização da monocultura canavieira, em Dracena, pode ser mensurada pelos dados referentes à área ocupada pela cana-de-açúcar no município (Tabela 4). Em 2005, a área ocupada pela cana-de-açúcar era de 1.260 hectares. No ano de 2013, a área plantada era de 12.740 hectares, evidenciando aumento de $911,1 \%$.

Tabela 4. Dracena - SP: área plantada de cana-de-açúcar (2000 - 2013)

\begin{tabular}{|l|c|c|c|c|}
\hline \multirow{2}{*}{ Tipo de lavoura } & $\mathbf{2 0 0 0}$ & $\mathbf{2 0 0 5}$ & $\mathbf{2 0 1 0}$ & $\mathbf{2 0 1 3}$ \\
\cline { 2 - 5 } & Área (hectares) & Área (hectares) & Área (hectares) & Área (hectares) \\
\hline Cana-de-açúcar & - & 1.260 & 10.890 & 12.740 \\
\hline
\end{tabular}

*Os dados do ano 2000 não foram disponibilizados pelo IBGE.

Fonte: Produção Agrícola Municipal - IBGE, 2015.

Nas figuras 3 e 4, podemos notar a expansão da cana-de-açúcar, por meio das alterações no uso e ocupação da terra, no município de Dracena, entre os anos 2000 e 2013. A Figura 3 apresenta as áreas ocupadas pelos eucaliptais no ano de 2000.

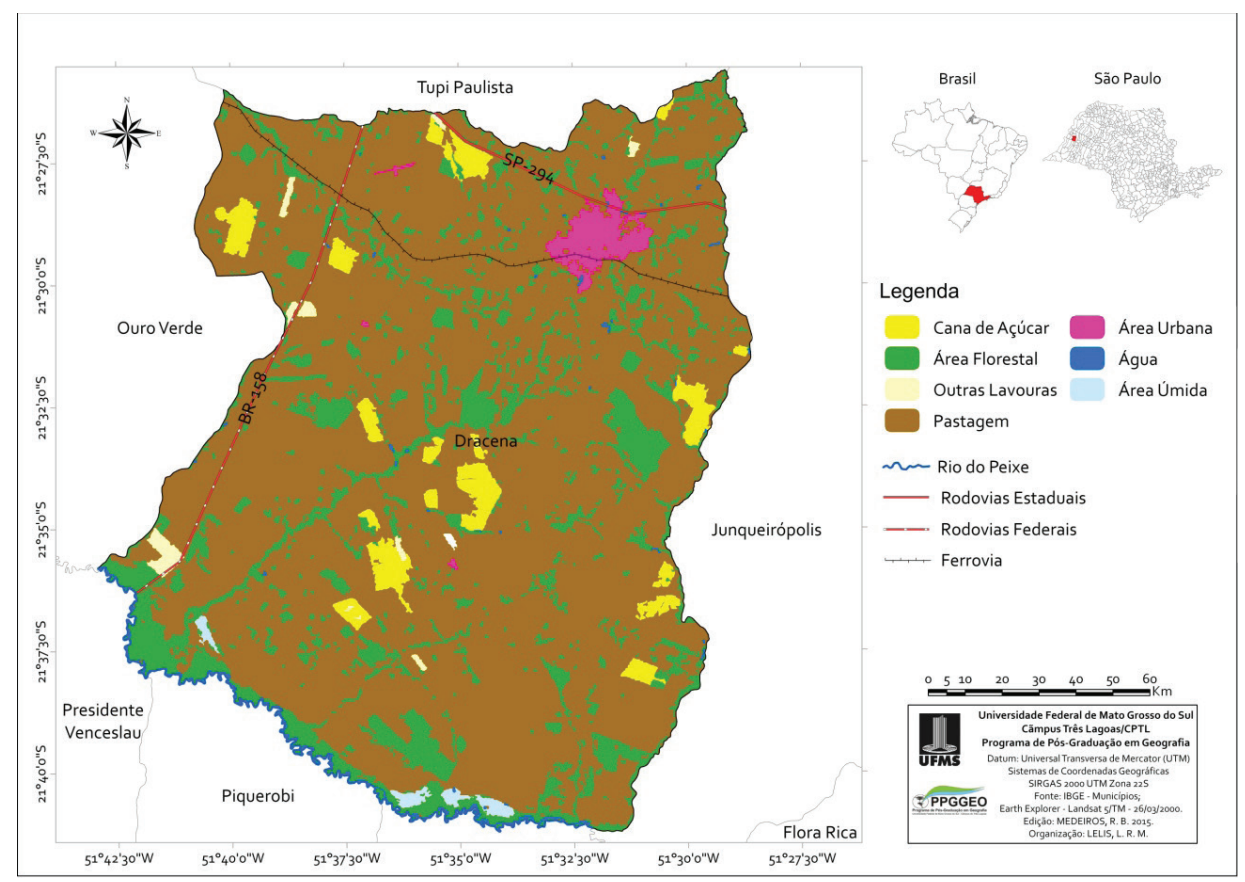

Figura 3. Dracena - SP: uso e ocupação da terra no ano de 2000 Fonte: IBGE, 2015. Org.: LELIS, 2015. 
Conforme a Figura 3, em 2000, poucas áreas eram ocupadas pelos canaviais. No entanto, em 2013, podemos notar significativa ampliação das áreas ocupadas pela monocultura de cana-de-açúcar (Figura 4).

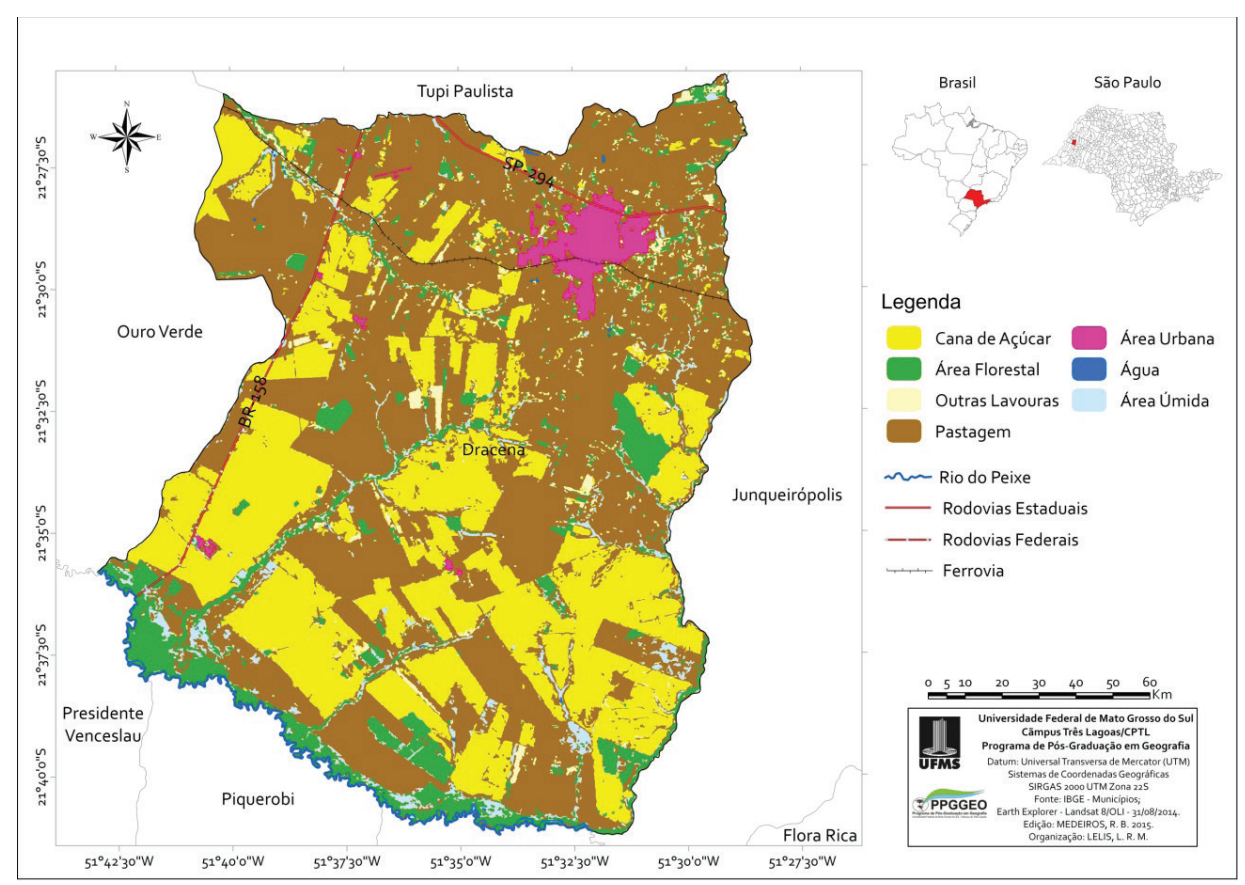

Figura 4. Dracena - SP: uso e ocupação da terra no ano de 2013

Fonte: IBGE, 2015. Org.: LELIS, 2015.

O crescimento da produção de cana-de-açúcar (Tabela 5) é outro indício da territorialização da monocultura canavieira em Dracena. No ano de 2005, a cana-deaçúcar registrou produção de 125.155 toneladas. Em 2013, a produção aumentou para 1.200.000 toneladas. Comparando as produções dos anos de 2005 e 2013, podemos crescimento percentual de $858,8 \%$.

Tabela 5. Dracena - SP: quantidade produzida de cana-de-açúcar $(2000$ - 2013)

\begin{tabular}{|l|c|c|c|c|}
\hline \multirow{2}{*}{ Tipo de lavoura } & $\mathbf{2 0 0 0}$ & $\mathbf{2 0 0 5}$ & $\mathbf{2 0 1 0}$ & $\mathbf{2 0 1 3}$ \\
\cline { 2 - 5 } & $\begin{array}{c}\text { Quantidade } \\
\text { (toneladas) }\end{array}$ & $\begin{array}{c}\text { Quantidade } \\
\text { (toneladas) }\end{array}$ & $\begin{array}{c}\text { Quantidade } \\
\text { (toneladas) }\end{array}$ & $\begin{array}{c}\text { Quantidade } \\
\text { (toneladas) }\end{array}$ \\
\hline Cana-de-açúcar & - & 125.155 & 988.191 & 1.200 .000 \\
\hline
\end{tabular}

*Os dados do ano 2000 não foram disponibilizados pelo IBGE.

Fonte: Produção Agrícola Municipal - IBGE, 2015. 
Na Tabela 6, podemos notar os dados referentes ao valor gerado pela produção de cana-de-açúcar no município de Dracena entre os anos de 2005 e 2013. Em 2005, a produção de cana-de-açúcar gerou R\$ 3.504.000,00. Em 2013, esse valor cresceu significativamente e alcançou R\$ 66.360.000,00. Comparando os anos de 2005 e 2013, o crescimento foi de $1.793,8 \%$.

Tabela 6. Dracena - SP: valor da produção da cana-de-açúcar (2000 - 2013)

\begin{tabular}{|l|c|c|c|c|}
\hline \multirow{2}{*}{ Tipo de lavoura } & $\mathbf{2 0 0 0}$ & $\mathbf{2 0 0 5}$ & $\mathbf{2 0 1 0}$ & $\mathbf{2 0 1 3}$ \\
\cline { 2 - 5 } & $\begin{array}{c}\text { Valor } \\
\text { (mil reais) }\end{array}$ & $\begin{array}{c}\text { Valor } \\
\text { (mil reais) }\end{array}$ & $\begin{array}{c}\text { Valor } \\
\text { (mil reais) }\end{array}$ & $\begin{array}{c}\text { Valor } \\
\text { (mil reais) }\end{array}$ \\
\hline Cana-de-açúcar & - & 3.504 & 41.504 & 66.360 \\
\hline
\end{tabular}

*Os dados do ano 2000 não foram disponibilizados pelo IBGE.

Fonte: Produção Agrícola Municipal - IBGE, 2015.

Os dados de fontes secundárias, bem como as figuras 1 e 2, evidenciam a territorialização da monocultura canavieira em Dracena. A referida territorialização proporcionou inúmeras desvantagens para o município pesquisado, tendo em conta que os impactos socioambientais gerados por essa expansão são extremamente significativos.

A territorialização da monocultura canavieira proporcionou impactos sociais em decorrência da sazonalidade da maioria dos empregos gerados por esse setor econômico, da exploração dos trabalhadores rurais, da desarticulação de comunidades rurais, da ampliação da concentração de renda e de terra, da dificuldade imposta para o desenvolvimento do campesinato e da redução das áreas e das produções dos outros tipos de atividades agropecuárias, culminando na redução de culturas alimentares, do efetivo animal e da produção de origem animal (SEGATTI, 2009; LELIS; HESPANHOL, 2013).

A Tabela 7 apresenta as produções das principais lavouras temporárias do município de Dracena durante o período analisado. Conforme essa tabela, a lavoura de amendoim foi a única que apresentou crescimento. Enquanto isso, as lavouras de feijão, mandioca e milho reduziram e a lavoura de algodão foi extinta.

Tabela 7. Dracena - SP: produção das principais lavouras temporárias $(2000$ - 2013)

\begin{tabular}{|l|c|c|c|c|}
\hline \multirow{2}{*}{ Tipo de lavoura } & $\mathbf{2 0 0 0}$ & $\mathbf{2 0 0 5}$ & $\mathbf{2 0 1 0}$ & $\mathbf{2 0 1 3}$ \\
\cline { 2 - 5 } & $\begin{array}{c}\text { Quantidade } \\
\text { (toneladas) }\end{array}$ & $\begin{array}{c}\text { Quantidade } \\
\text { (toneladas) }\end{array}$ & $\begin{array}{c}\text { Quantidade } \\
\text { (toneladas) }\end{array}$ & $\begin{array}{c}\text { Quantidade } \\
\text { (toneladas) }\end{array}$ \\
\hline Algodão & 472 & 380 & - & - \\
\hline Amendoim & 1.205 & 726 & 60 & 1.791 \\
\hline Feijão & 655 & 1.710 & 240 & 168 \\
\hline Mandioca & 240 & 2.747 & 1.440 & 997 \\
\hline Milho & 4.320 & 4.320 & 2.568 & 2.037 \\
\hline
\end{tabular}

Fonte: Produção Agrícola Municipal - IBGE, 2015. 
Todas as produções das principais lavouras permanentes de Dracena, registradas no ano de 2013, foram inferiores quando comparadas com produções de anos anteriores. Destaque para a produção laranja, que a partir de 2005 não foi mais registrada (Tabela 8).

Tabela 8. Dracena - SP: produção das principais lavouras permanentes $(2000$ - 2013)

\begin{tabular}{|l|c|c|c|c|}
\hline \multirow{2}{*}{ Tipo de lavoura } & $\mathbf{2 0 0 0}$ & $\mathbf{2 0 0 5}$ & $\mathbf{2 0 1 0}$ & $\mathbf{2 0 1 3}$ \\
\cline { 2 - 5 } & $\begin{array}{c}\text { Quantidade } \\
\text { (toneladas) }\end{array}$ & $\begin{array}{c}\text { Quantidade } \\
\text { (toneladas) }\end{array}$ & $\begin{array}{c}\text { Quantidade } \\
\text { (toneladas) }\end{array}$ & $\begin{array}{c}\text { Quantidade } \\
\text { (toneladas) }\end{array}$ \\
\hline Banana & 15 & 1.625 & 96 & 160 \\
\hline $\begin{array}{l}\text { Café } \\
\text { em grão) }\end{array}$ & 1.200 & 444 & 1.202 & 900 \\
\hline Laranja & 423 & - & - & - \\
\hline Manga & 4.473 & 2.592 & 1.116 & 2.500 \\
\hline Maracujá & 642 & 405 & 210 & 72 \\
\hline Uva & 598 & 180 & 270 & 220 \\
\hline
\end{tabular}

Fonte: Produção Agrícola Municipal - IBGE, 2015.

Com exceção do rebanho de ovinos, todos os outros rebanhos de animais apresentaram redução entre os anos de 2000 e 2013. Destaque para o rebanho bovino, que apresentou decréscimo de $43,7 \%$, e para o efetivo de galináceos, que registrou redução de $66,6 \%$ (Tabela 9).

Tabela 9. Dracena - SP: efetivo dos principais rebanhos (2000 - 2013)

\begin{tabular}{|l|c|c|c|c|}
\hline \multirow{2}{*}{ Tipo de rebanho } & $\mathbf{2 0 0 0}$ & $\mathbf{2 0 0 5}$ & $\mathbf{2 0 1 0}$ & $\mathbf{2 0 1 3}$ \\
\cline { 2 - 5 } & Quantidade & Quantidade & Quantidade & Quantidade \\
\hline Bovino & 57.243 & 51.256 & 40.121 & 32.200 \\
\hline Equino & 1.280 & 810 & 1.010 & 950 \\
\hline Galináceos & 125.000 & 103.000 & 63.800 & 42.000 \\
\hline Ovino & 1.100 & 1.150 & 2.130 & 2.344 \\
\hline Suíno & 2.050 & 1.800 & 1.890 & 1.910 \\
\hline
\end{tabular}

Fonte: Pesquisa Pecuária Municipal - IBGE, 2015.

A produção de leite, mesmo passando por altos e baixos, foi o único tipo de produção de origem animal que apresentou crescimento no município de Dracena durante o período analisado. As produções de ovos de galinha e de mel de abelha registraram decréscimo, enquanto a produção de casulos do bicho-da-seda foi extinta do município estudado (Tabela 10). 
Tabela 10. Dracena - SP: principais produções de origem animal (2000 - 2013)

\begin{tabular}{|l|c|c|c|c|}
\hline \multirow{2}{*}{ Tipo de produção } & $\mathbf{2 0 0 0}$ & $\mathbf{2 0 0 5}$ & $\mathbf{2 0 1 0}$ & $\mathbf{2 0 1 3}$ \\
\cline { 2 - 5 } & Quantidade & Quantidade & Quantidade & Quantidade \\
\hline Leite (mil litros) & 4.831 & 3.900 & 3.100 & 4.840 \\
\hline $\begin{array}{l}\text { Ovos de galinha } \\
\text { (mil dúzias) }\end{array}$ & 1.350 & 1.230 & 600 & 510 \\
\hline Mel de abelha (kg) & 1.800 & 1.100 & 710 & 545 \\
\hline $\begin{array}{l}\text { Casulos do bicho- } \\
\text {-da-seda (kg) }\end{array}$ & 24.192 & 4.847 & - & - \\
\hline
\end{tabular}

Fonte: Pesquisa Pecuária Municipal - IBGE, 2015.

No que se refere aos impactos ambientais, a poluição do solo, do ar e dos recursos hídricos devido à utilização demasiada de agrotóxicos, a diminuição da biodiversidade e as queimadas figuram como alguns dos principais problemas ambientais gerados pela expansão da monocultura canavieira. Não é só no campo que a fumaça e a fuligem das queimadas da cana-de-açúcar são facilmente notadas, pois elas também chegam até a cidade. Além disso, as queimadas também provocam a morte de animais. A proliferação de pragas e doenças derivadas da cultura canavieira em culturas circunvizinhas também figura como um dos impactos negativos para o meio ambiente (SEGATTI, 2009; LELIS; HESPANHOL, 2013).

\section{A resistência camponesa frente à territorialização da cana-de-açúcar em Dracena}

O município de Dracena é caracterizado, desde o início de sua formação, pela grande presença do campesinato. Isso porque, sua formação ocorreu em virtude da expansão da cultura cafeeira para o Oeste do Estado de São Paulo, na década de 1940. Em Dracena, a maior parte das lavouras de café era cultivada pelos camponeses que adquiriram pequenas porções de terras junto às empresas colonizadoras (GIL, 2007; LELIS; HESPANHOL, 2014).

Durante décadas, o café constitui-se como principal produto dos camponeses. Todavia, essa situação foi alterada a partir da década de 1980. Nesta década, a crise do café proporcionou novo momento para os camponeses. Para continuar no campo, os camponeses tiveram de readequar-se produtivamente e os cafezais foram substituídos, principalmente, pelas pastagens e pela fruticultura. As décadas de 1980 e 1990 foram de extrema dificuldade para o desenvolvimento do campesinato em Dracena. A partir do início da década de 2000, a situação passou a melhorar em virtude, principalmente, da implementação de políticas públicas rurais. Entretanto, também foi a partir do início da década de 2000 que ocorreu o início do processo de territorialização da cana-de-açúcar em Dracena, que, atualmente, é um dos principais obstáculos para o desenvolvimento do campesinato no município analisado (LELIS; HESPANHOL, 2014).

A partir da aplicação do questionário junto aos camponeses, averiguamos que, atualmente, a estrutura produtiva camponesa é caracterizada pelo predomínio do setor hortifrutigranjeiro e da pecuária leiteira. Mesmo após a crise do café da década de 1980, 
que atingiu profundamente os camponeses do município pesquisado, averiguamos que alguns camponeses dracenenses ainda possuem plantações de café, tendo em vista que dos 25 camponeses pesquisados, 8 (32\%) ainda cultivam café.

Nem todos os camponeses pesquisados de Dracena conseguem identificar a influência negativa da expansão dos canaviais em suas atividades desenvolvidas, pelo contrário, 9 (36\%) camponeses afirmaram não considerar a expansão da cana-de-açúcar como obstáculo. Enquanto isso, 16 (64\%) camponeses pesquisados identificaram que, após a expansão da lavoura canavieira, aumentaram as dificuldades para continuar produzindo no campo e os problemas relacionados ao meio ambiente.

Os camponeses pesquisados afetados pela expansão da cana-de-açúcar no município alegaram diversos motivos, tais como: destruição de lavouras em decorrência dos agrotóxicos pulverizados nos canaviais; deterioração de estradas rurais, em virtude da circulação de caminhões que transportam cana-de-açúcar; diminuição do número de trabalhadores rurais; desequilíbrio biológico; e, aumento do número de pragas e doenças.

A destruição de lavouras em virtude de agrotóxicos ocorreu com alguns dos pesquisados e, segundo relatos, proporcionou prejuízos financeiros. Mesmo os que não tiveram suas lavouras afetadas afirmaram que já ouviram relatos de camponeses vizinhos de canaviais que tiveram suas lavouras danificadas pelos agrotóxicos. Os depoimentos abaixo contemplam inúmeros problemas gerados pela expansão dos canaviais em Dracena, na visão dos camponeses:

Os pé de manga e de laranja tão sendo prejudicados. A laranja não tá segurando no pé. Quando ela cresce um pouco ela cai. O pé não tá tendo força para segurar a laranja. $\mathrm{O}$ chão tá forrado de laranja. Eu nunca vi isso. Pelo que os outros falam, é por causa do veneno da cana (P. E. B., 19/03/2015).

A cana atrapalha muito. Os lago e os córgo aqui perto não têm mais peixe. Eu acho que é por causa do veneno usado na cana. O pessoal tudo também acha. Só não temos como provar. A gente não tem estudo. Não dá pra provar, mas a gente percebe que isso tem a ver $\operatorname{sim}$ (L. A. S., 19/03/2015).

Tem o problema cos veneno da cana, porque os pé de manga começo a morre. É só olhar aqui. Olha os pé de manga. Tão tudo seco. Não dá mais manga. Diz que é por causa do veneno da cana, tem gente que diz que é por causa disso, eu não posso afirmar, não tenho como provar (J. F., 26/03/2015).

Eu acho que a cana tá atrapaiano as otra lavora, porque todo mundo só tá plantano cana. Aí também tem o veneno que acaba cas lavoura. Isso é muito ruim pra quem tem lavoura perto da cana. Eu não tenho, mas já ouvi muita gente reclamano que perdeu a lavoura (J. A. R., 26/03/2015).

Pra mim atrapalha muito. A gente tá cercado pela cana. Acaba com as estradas. Também tem o veneno que é o maior problema pra mim. Tá atrapalhano a minha produção. Porque eu tô trabalhando com bicho-da-seda. Eu alimento eles com amora e o veneno que os aviões joga tão chegando nas amora. Elas tão ficano envenenada. Aí eu alimento os bichos com elas e os bichos tão morreno. 
Já fui reclamar com o pessoal da usina, mas não acontece nada. Continua a mesma coisa. Eles fala que não tem nada a ver, mas é claro que tem (S. C. F., 02/04/2015).

A cana atrapalha sim! Tudo que a gente planta morre por causa dos veneno. Nada dá certo. A gente tá cercado pela cana aqui no assentamento, sempre tem avião jogano veneno. $\mathrm{O}$ veneno vem pelo ar. [...] As estradas também sempre tá ruim. Isso atrapalha bastante, porque a gente tá no meio dos canaviais e depende dessas estradas (T. M. A., 02/04/2015).

A deterioração das estradas rurais em função do tráfego de caminhões que fazem o transporte da produção canavieira também foi um ponto em comum entre os camponeses prejudicados pela expansão da cana-de-açúcar em Dracena. De acordo com esses camponeses pesquisados, as reformas das estradas são rapidamente superadas, principalmente no período de colheita.

Alguns pesquisados também relataram que, a partir da expansão da cana-deaçúcar, o número de trabalhadores rurais disponíveis diminuiu. Além da escassez de trabalhadores rurais, existe outro problema: o valor elevado da mão de obra dos que estão disponíveis. Segundo os camponeses, o custo elevado da mão de obra inviabiliza a contratação de trabalhadores na época da colheita, período em que boa parte das unidades produtivas camponesas precisa aumentar o número de trabalhadores para suprir as necessidades.

A cana hoje dificulta, porque entrou muito maquinário, aí diminuiu a mão de obra. Eu mesmo já trabaiei no corte de cana. Era ruim trabaia lá, mas era o que tinha na época, era onde eu tirava o sustento da minha família. O pessoal trabaia na usina, não quer mais trabalhar por dia. A gente não consegue paga o que eles pede. É caro pra gente. Não tem gente pra trabalha, mas quando tem, é caro. Tem menos gente pra trabalha na roça hoje (J. A. R., 26/03/2015).

Mesmo sem o amparo de estudos científicos, alguns camponeses apontaram um possível desequilíbrio ecológico em Dracena devido à expansão dos canaviais. Amparados nos conhecimentos próprios adquiridos ao longo de muitos anos no campo, alguns camponeses também apontaram que, após a expansão da cana-de-açúcar, houve aumento do número e da variedade de pragas e doenças. A respeito do aumento de pragas, o camponês P. E. B. relatou:

Aumento as pragas. Antes não tinha tantas. Depois que começo a cana, de uns 10 anos pra cá, começou a ter praga que não tinha antes. Todo mundo fala que é por causa da cana. Pra mim teve um desequilíbrio na natureza. Você vê animais que não tinha aqui antes. Eles tão sem alimento no lugar deles, porque tudo virou cana. Aí eles têm que ficar vindo perto na cidade. Até na cidade dá pra ver um monte de bicho (P. E. B., 19/03/2015).

Cientes dos problemas gerados pela expansão da cana-de-açúcar, os camponeses que a consideram como obstáculo são contra a referida monocultura, evidenciando a resistência camponesa em relação à territorialização do capital no campo, conforme relato do Sr. J. A.: 
A cana acaba com tudo, destrói tudo. Pra mim ela acaba com a terra, deixa a terra pobre. Eu não tenho muita terra, mas se eu tivesse, não arrendaria pra cana de jeito nenhum. Eu prefiro não ganhar dinheiro do que ganhar dinheiro com cana. Cana é uma coisa que você nunca vai ver aqui (J. A., 19/03/2015).

Os camponeses pesquisados de Dracena que relataram acreditar que a expansão da monocultura se configura como obstáculo para o desenvolvimento do campesinato parecem possuir visão política mais ampliada. De acordo com os questionários, esses camponeses são aqueles mais ativos nas atividades desenvolvidas pela associação ou cooperativa em que participam.

A respeito das maiores dificuldades para o desenvolvimento de suas atividades produtivas no campo (Figura 5), os camponeses pesquisados de Dracena citaram que os maiores obstáculos são: falta de apoio e incentivo governamental (24), condições climáticas (23), estradas em condições ruins e falta de assistência técnica (19), falta de mão de obra (18), falta de melhores técnicas e equipamentos (17), dificuldade na comercialização (14) e expansão da cana-de-açúcar (13). Cinco camponeses pesquisados do Assentamento Nova Canaã, onde estão há apenas dois anos, citaram a falta de água encanada, energia elétrica e moradia. Ainda houve dificuldades citadas apenas uma vez, como: alto custo para produzir, demora para receber o pagamento das políticas públicas, burocracia das políticas públicas e idade avançada. O depoimento do camponês dracenense C. M. S., por exemplo, elucida uma série de dificuldades que os camponeses enfrentam para o desenvolvimento de suas atividades em Dracena:

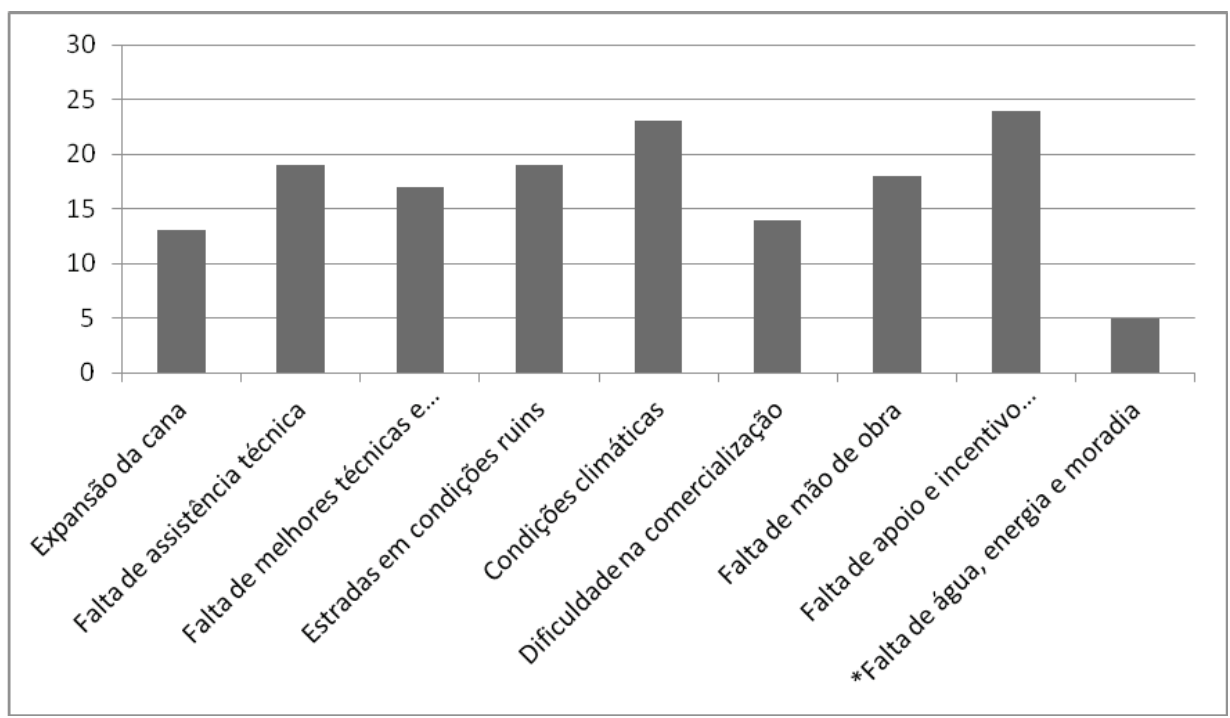

Figura 5. Dracena - SP: principais dificuldades encontradas pelos pesquisados para o desenvolvimento das atividades da propriedade

*Camponeses do Assentamento Nova Canaã.

Fonte: Trabalho de campo, mar./abr./2015. 
Eu acho que falta um monte de coisa que você falo aí. Falta apoio do governo, porque o governo só dá apoio pros fazendeiro. O governo só olha pra eles, mas eles já têm muito dinheiro. A gente que não tem dinheiro, também não tem apoio. Aí fica difícil pra gente. Hoje tá difícil pra quem tá querendo produzi e não tem dinheiro. Fica difícil. Na maioria das vez a gente toma prejuízo, mas mesmo assim a gente insiste. [...] Agrônomo, Veterinário, não passa aqui não. A gente não tem nada disso. Nunca teve. Mas seria bom se tivesse uma ajuda. É sempre bom. [...] Agora as venda tá melhor, porque a gente entrega lá na Fapidra $^{3}$, mas antes era mais difícil. $\mathrm{O}$ valor que eles paga é pouco, tem uma cota, poderia ser melhor, mas a gente não pode reclamar, porque já foi pior sem isso (C. M. S., 13/03/2015).

Mesmo com as dificuldades enfrentadas para o desenvolvimento de suas atividades no campo, apenas dois $(8 \%)$ dos 25 camponeses pesquisados de Dracena afirmaram a intenção de migrar para a cidade. Enquanto isso, os outros $23(92 \%)$ pesquisados pretendem continuar no campo desenvolvendo suas atividades agropecuárias. Joviano (2009), em sua pesquisa de mestrado, também notou a resistência camponesa frente à territorialização do capital em um bairro rural de Dracena:

Ainda sobre a territorialização da cana, verifica-se que, no bairro do Prado, onde desde o período da colonização do município predominam as pequenas unidades de produção, o setor sucroalcooleiro não conseguiu entrar, não havendo no bairro propriedades com arrendamento para plantio de cana-deaçúcar, evidenciando que onde há preponderância do modo de vida camponês, a resistência em relação à territorialização do capital é maior (JOVIANO, 2009, p. 161).

Assim, mesmo com o contexto desfavorável para o desenvolvimento do campesinato, o camponês dracenense J. A. foi enfático ao relatar o intuito de permanecer no campo:

Eu não gosto da cidade. Eu gosto de mora na roça. Aqui é melhor pra mim. Aqui nóis tem mais liberdade. Eu sempre morei na roça, em vários lugares. Antes eu morava na Sete Casas. Aí depois consegui compra aqui [...] Eu nunca passei fome aqui. Sempre tive o que come. Na cidade se passa muitas dificuldade as veiz. Eu vejo isso. Aqui tem fartura. Não passa fome não. É só trabaia [...] Tá difícil hoje em dia fica na roça. Isso é verdade, mas eu não desisto não. Eu gosto daqui né?! Não tem jeito. Nasci e fui criado na roça. Criei meus filho. Passei minha vida inteira na roça. Da roça não vô saí não. Pode acontecer o que for, mas só vô saí daqui direto pro cemitério (risos) (J. A., 19/03/2015).

De acordo com os questionários, a combinação de diferentes fontes de renda (Figura 6) faz parte das estratégias camponesas para permanecer na terra, resistindo às adversidades impostas pelo capital. Segundo os camponeses pesquisados, a combinação de diferentes fontes de renda é importante para a reprodução familiar e para o

3. Local onde funciona a Associação dos Produtores Rurais de Dracena (APRD) e onde são entregues os produtos das políticas públicas rurais, como o Programa de Aquisição de Alimentos (PAA) e o Programa Nacional de Alimentação Escolar (PNAE). 
desenvolvimento das atividades da unidade de produção camponesa. Entre as fontes de renda mais citadas, estão: comercialização da produção (21) $)^{4}$, aposentadoria (13), trabalho na cidade (9), participação em políticas públicas rurais (7) e aluguel de imóvel (5).

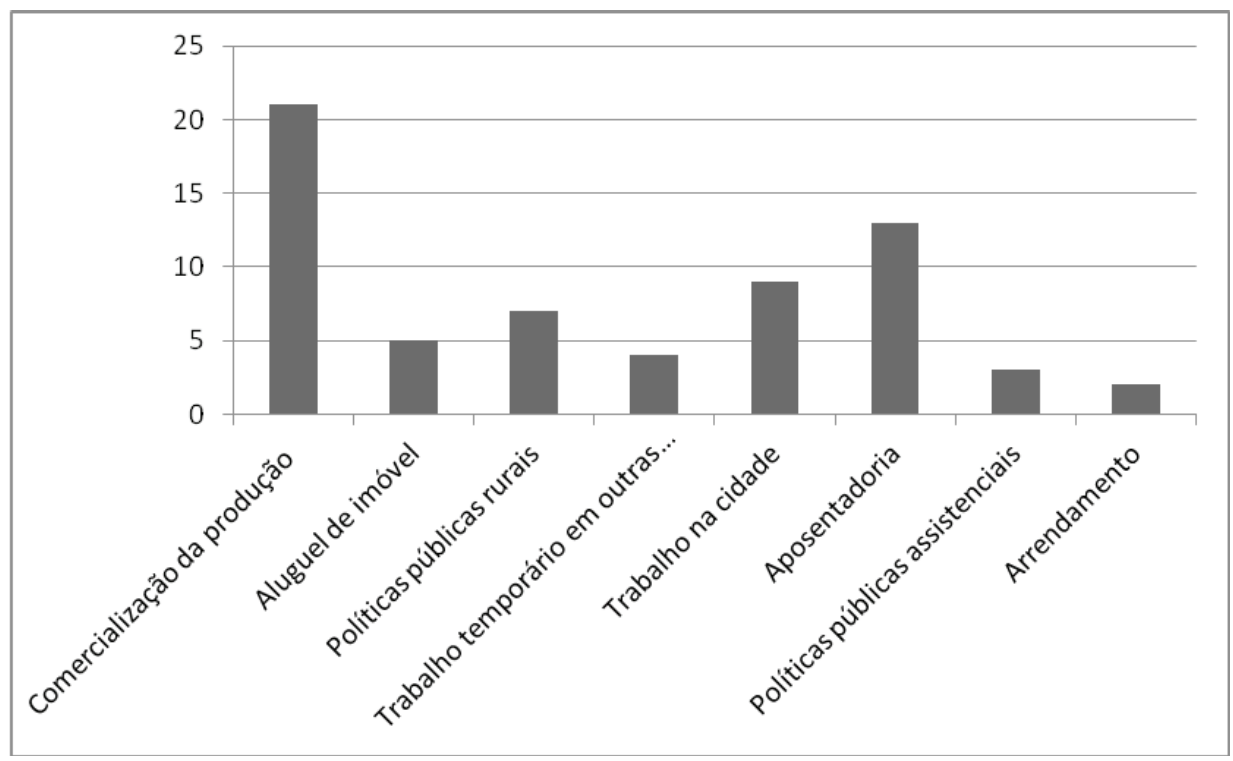

Figura 6. Dracena - SP: principais fontes de renda dos camponeses pesquisados Fonte: Trabalho de campo, mar./abr./2015.

Entre os 17 camponeses que afirmaram possuir renda oriunda da aposentadoria, do trabalho na cidade e do aluguel de imóveis, 9 (53\%) relataram que essas fontes de renda contribuem para o desenvolvimento das atividades agropecuárias da unidade produtiva camponesa. Essas fontes de renda não agrícolas, muitas vezes, contribuem para a aquisição de adubos e fertilizantes, para o pagamento da prestação de serviços e de melhoria da infraestrutura, entre outras necessidades.

Apesar da importância da combinação de diferentes fontes de renda para a permanência dos camponeses no campo, averiguamos que os principais fatores viabilizadores dessa permanência não são de ordem econômica, pelo contrário, são relacionados ao modo de vida camponês, pois os fatores mais citados foram: afetividade com o lugar e tranquilidade da vida no campo (25), interesse pelo trabalho rural (22) e propriedade adquirida por meio de muitos esforços $(20)^{5}$ (Figura 7). A afetividade com o lugar, os esforços para a aquisição da propriedade, a tranquilidade da vida no

4. Os camponeses de Dracena que não comercializam parte da produção afirmaram que os produtos são consumidos apenas pela família. O excedente é doado para os vizinhos e/ou familiares que vivem na cidade.

5. Os camponeses assentados ainda não são proprietários de fato da terra, no entanto, lutaram para conseguir aquele pedaço de terra, que, portanto, foi conseguido por meio de muitos esforços. 
campo e o interesse pelo trabalho rural podem ser notadas no depoimento do camponês dracenense A. A.:

Eu gosto de mora na roça. Eu nasci na roça, fui criado na roça e daqui eu não saio por nada. Eu tenho filhos na cidade, eles me chama direto pra ir pra lá, mas eu não vou, meu lugar é aqui. [...] Tive que trabalha muito pra compra isso aqui. Foi muitos anos no café, trabalhano de empregado. Foi sofrido. Eu e a muié trabalhamo bastante pros outros. [...] Aqui é sussegado, a gente não tem problema. A gente vive tranquilo aqui. Na cidade é outra coisa, lá tem coisa que não tem aqui. É perigoso. Aqui a gente dorme com a janela aberta, lá não tem como faze isso. Tem que vive fechado lá. Isso é ruim. Não gosto de vive preso igual o povo da cidade não [...] Eu gosto de trabalha na roça. Eu fiz isso minha vida toda. Se eu for pra cidade, vou fazer o que lá? Eu só sei trabalha na roça memo. Tudo o que eu tenho, eu consegui na roça, trabalhano muito. Aqui eu fico ocupado o dia intero. Sempre tem coisa pra faze (A. A., 13/03/2015).

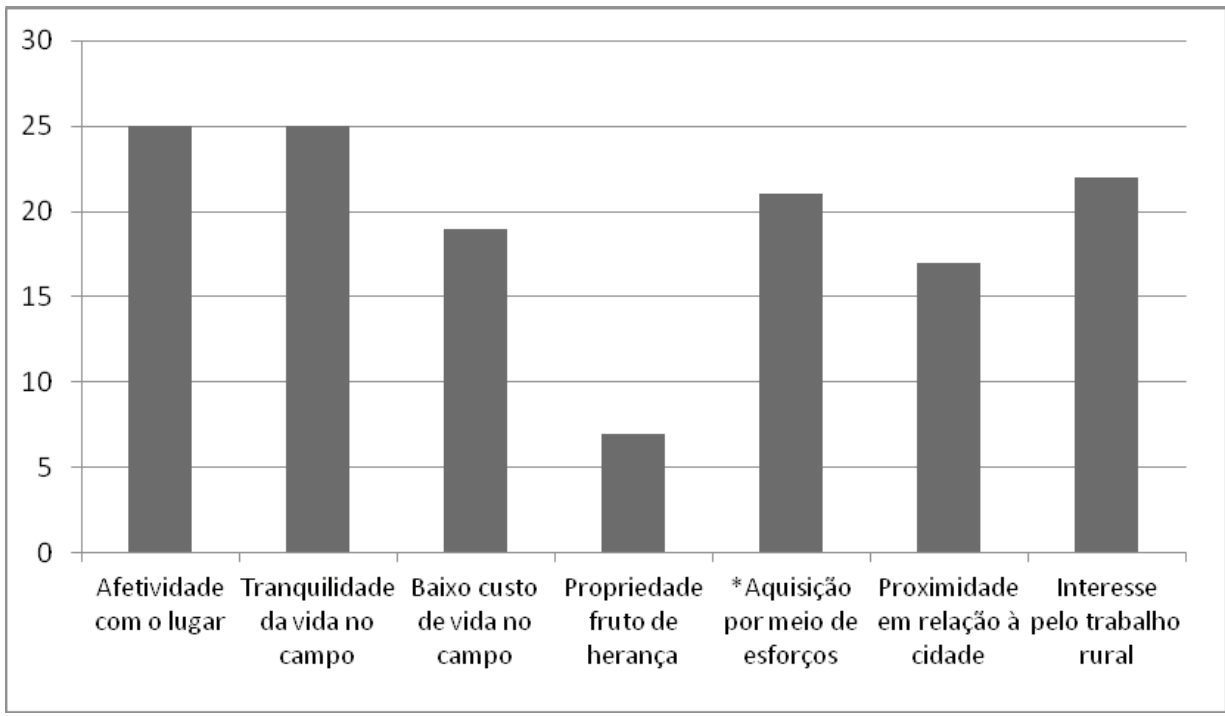

Figura 7. Dracena - SP: fatores que influenciam na permanência dos camponeses pesquisados no campo

*Inclui os assentados que ainda não são proprietários de fato da terra.

Fonte: Trabalho de campo, mar./abr./2015.

Os principais fatores viabilizadores da permanência dos camponeses no campo não são de ordem econômica, pelo contrário, são fatores ligados ao modo de vida camponês, pautado na tríade terra, trabalho e família (WOORTMANN, 1990; ALMEIDA, 2006). Essa situação reforça a tese que as terras utilizadas pelos camponeses e pelos capitalistas possuem interesses e resultados distintos, pois enquanto a terra utilizada pelos camponeses é terra de trabalho e de reprodução familiar, a terra utilizada 
pelos capitalistas é terra de negócio, de exploração do trabalho alheio e do meio ambiente (MARTINS, 1980).

\section{Considerações finais}

Os processos de territorialização do capital e de modernização da agricultura proporcionaram transformações estruturais no campo brasileiro, principalmente a partir da década de 1960, provocando alterações e impactos significativos na dinâmica social, econômica e ambiental do campo brasileiro. Entretanto, apesar de favorecerem a classe dominante, esses processos também abriram espaço para ampliação da luta camponesa pela terra, reprimida violentamente pelos capitalistas. Todavia, mesmo com a violência e a barbárie, o campesinato segue sua trajetória de luta para entre e permanecer na terra.

No município de Dracena, a territorialização da monocultura canavieira provocou diversos impactos socioambientais, tais como: exploração dos trabalhadores rurais, desarticulação de comunidades rurais, redução de culturas alimentares, do efetivo animal e da produção de origem animal, poluição do solo, do ar e da água, diminuição da biodiversidade, entre outros. Boa parte destes impactos foram constatados pelos próprios camponeses pesquisados, conforme evidenciado nos depoimentos.

Por consequência dos diversos impactos socioambientais causados no campo, ficou evidente que a territorialização da monocultura canavieira também tem dificultado o desenvolvimento do campesinato dracenense. No entanto, mesmo com contexto desfavorável, a grande maioria dos camponeses analisados afirmaram que não pretendem deixar o campo. Apesar da importância da combinação de diferentes fontes de renda para a permanência dos camponeses no campo, averiguamos que os principais fatores viabilizadores dessa permanência não são de ordem econômica, mas sim, relacionados ao modo de vida camponês. Tal situação evidencia a resistência camponesa perante as adversidades impostas pela territorialização do capital no campo.

\section{Agradecimentos}

Agradecemos à Fundação de Apoio ao Desenvolvimento do Ensino, Ciência e Tecnologia do Estado de Mato Grosso do Sul (FUNDECT) por viabilizar financeiramente o desenvolvimento desta pesquisa.

\section{Referências}

ALMEIDA, R. A. (Re)criação do campesinato, identidade e distinção: a luta pela terra e o habitus de classe. $1^{\text {a }}$ ed. São Paulo: Editora UNESP, 2006.

. A territorialização do agronegócio do eucalipto na região leste de Mato Grosso

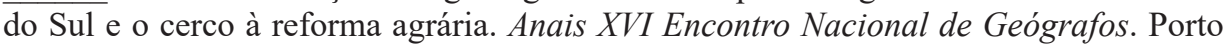
Alegre, 2010.

- Territorialização complexo eucalipto-celulose-papel em Mato Grosso do Sul. Anais XXI Encontro Nacional de Geografia Agrária. Uberlândia, 2012. p. 1-19. 
Disponível em: <http://www.lagea.ig.ufu.br/xx1enga/anais_enga_2012/eixos/1291_1. pdf $>$. Acesso em: 14 jan. 2014.

ANDRADE, M. C. Agricultura e capitalismo. São Paulo: LECH, 1979.

BEDUN, M. R. Os desafios da agricultura familiar camponesa frente à territorialização do agronegócio: perspectivas para o município de Tupi Paulista e seu entorno regional. Dissertação (Mestrado em Geografia). 2012. 138 f. Universidade Federal de Mato Grosso do Sul, Três Lagoas, 2012.

CPT. Comissão Pastoral da Terra. Conflitos no campo Brasil (2000 a 2013). Disponível em: <http://www.cptnacional.org.br/index.php/component/jdownloads/viewcategory/ 43-conflitos-no-campo-brasil-publicacao?Itemid=23>. Acesso em: 12 jan. 2015.

FABRINI, J. E. O campesinato frente à expansão do agronegócio e do agrocombustível. In: SAQUET, M. A.; SANTOS, R. A. (Orgs.). Geografia agrária, territórios e desenvolvimento. ed. 1. São Paulo: Expressão Popular, 2010, p.55- 88.

. Território, classe e movimentos sociais no campo. Revista da ANPEGE, v. 7, n. 7, p. 97-112, jan./jul. 2011.

GIL, I. C. Nova Alta Paulista, 1930 - 2006: entre memórias e sonhos. Do desenvolvimento contido ao projeto político de desenvolvimento regional. 2007. 395 f. Tese (Doutorado em Geografia). Faculdade de Ciências e Tecnologia, Universidade Estadual Paulista, Presidente Prudente, 2007.

GIRARDI, E. P.; FERNANDES, B. M. Geografia das conflitualidades no campo brasileiro. In: FERNANDES, B. M.; MEDEIROS, L. S.; PAULILO, M. I. (Orgs.). Lutas camponesas contemporâneas: condições, dilemas e conquistas. Vol. 2. São Paulo: editora UNESP; Brasília, DF: Núcleo de estudos Agrários e Desenvolvimento Rural, 2009, p.339-366.

GRAZIANO DA SILVA, J. A modernização dolorosa: estrutura agrária, fronteira agrícola e trabalhadores rurais no Brasil. Rio de Janeiro: Zahar, 1982

IBGE. Instituto Brasileiro de Geografia e Estatística. Produção Agrícola Municipal (2000 a 2013). Disponível em <http://www.sidra.ibge.gov.br> acessado em: 15 fev. de 2015.

JOVIANO, C. V. M. Expropriação, luta e resistência: a questão camponesa no bairro "maquininha", município de Dracena-SP. 2009. 172 f. Dissertação (Mestrado em Geografia). Universidade Federal da Grande Dourados, Dourados, 2009.

LELIS, L. R. M.; HESPANHOL, R. A. M. Dinâmica agropecuária do município de Dracena - SP: da cafeicultura à cana-de-açúcar. Geografia em Questão, Marechal Cândido Rondon, v. 6, n. 2, p. 181-198, 2013. Disponível em: <http://e-revista.unioeste. br/index.php/geoemquestao/article/view/7805>. Acesso em: 30 jun. 2014.

. Os desdobramentos socioeconômicos da crise do café nas pequenas propriedades rurais do município de Dracena (SP). Campo - Território, Uberlândia, v. 9, n. 17, p. 230-255, abr. 2014. Disponível em: <http://www.seer.ufu.br/index.php/campoterritorio/ article/view/22706/14385>. Acesso em: 30 jun. 2014. 
MARTINS, J. S. Capitalismo e tradicionalismo: estudos sobre as contradições da sociedade agrária no Brasil. São Paulo: Pioneira, 1975.

1980

. Expropriação e Violência: a questão política no campo. São Paulo: Hucitec,

MATOS, P. F.; PESSÔA, V. L. S. Territorialização da agricultura moderna na região da estrada de ferro (Goiás) e as modificações no espaço agrário. Anais XIX Encontro Nacional de Geografia Agrária. São Paulo, 2009, p. 118.Disponível em: <http://www. geografia.fflch.usp.br/inferior/laboratorios/agraria/Anais\%20XIXENGA/artigos/Matos PF.pdf>. Acesso em: 15 jul. 2013.

. A modernização da agricultura no Brasil e os novos usos do território. Revista Geo UERJ. Ano 13, n. 22, v. 2. p. 290-322, 2011. Disponível em: <http://www.epublicacoes.uerj.br/index.php/geouerj/article/view/2456>. Acesso em: 15 jun. 2014.

OLIVEIRA, A. U. Modo Capitalista de Produção e Agricultura. ed. 4. São Paulo: Ática, 1995.

. A agricultura camponesa no Brasil. ed. 2. São Paulo: Contexto, 1996a.

. Agricultura Brasileira: Transformações Recentes. In: ROSS, J. L. S. (Org.), Geografia do Brasil. São Paulo: Edusp, 1996b, p. 467-534.

. Barbárie e modernidade: o agronegócio e as transformações no campo. Reunião da Coordenação Nacional da Comissão Pastoral da Terra (CPT), Goiânia, out. 2003, p. 1-52.

. Modo de Produção Capitalista, Agricultura e Reforma Agrária. São Paulo: Labur Edições, 2007.

THOMAZ JÚNIOR, A. Dinâmica Geográfica do Trabalho no Século XXI: Limites Explicativos, Autocrítica e Desafios Teóricos. Presidente Prudente, São Paulo, 2009.

WOORTMANN, K. "Com parente não se neguceia”. O campesinato como ordem moral. Anuário Antropológico. Brasília: DAN/UNB, 1990, p. 11-73. Disponível em: $<$ http://www.dan.unb.br/images/pdf/anuario_antropologico/Separatas1987/anuario87 woortmann.pdf >. Acesso em: 12 dez. 2014.

LEANDro Reginaldo MaXimino Lelis

Doutorando em Geografia pela Universidade Federal do Rio Grande do Norte. Mestre em Geografia da Universidade Federal de Mato Grosso do Sul, campus de Três Lagoas. Licenciado e Bacharel em Geografia pela Universidade Estadual Paulista, campus de Presidente Prudente.

Campus Universitário da UFRN, s/n. Lagoa Nova. CEP: 59078-970. Natal, RN -

Brasil.

E-mail: sukko51@hotmail.com 
Francisco José Avelino JúNIOR

Doutor em Geografia Humana pela Universidade de São Paulo. Licenciado e Bacharel em Geografia pela Faculdade Auxilium de Filosofia Ciências e Letras de Lins. Docente do Programa de Pós-Graduação em Geografia da Universidade Federal de Mato Grosso do Sul, campus de Três Lagoas.

Avenida Ranulpho Marques Leal, 3484. Distrito Industrial. CEP: 79613-000.

Três Lagoas, MS - Brasil.

E-mail: china.ufms@hotmail.com

Recebido para publicação em novembro de 2015 Aprovado para publicação em agosto de 2016 